IRA-International Journal of Education \& Multidisciplinary Studies

ISSN 2455-2526; Vol.07, Issue 03 (2017)

Pg. no. 270-278

Institute of Research Advances

http://research-advances.org/index.php/IJEMS

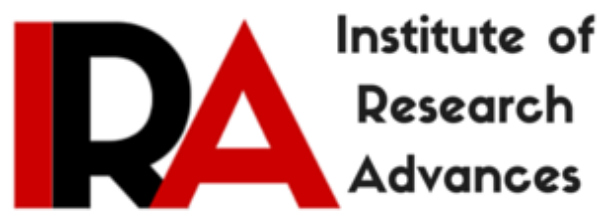

\title{
Internet Usage and Academic Achievement of Adolescents of West Bengal: An Exploratory Study
}

Bikram Maiti

Research Scholar, Department of Education, Vinaya Bhavana,

Visva Bharati, Santiniketan, India.

Type of Review: Peer Reviewed.

DOI: http://dx.doi.org/10.21013/jems.v7.n3.p12

How to cite this paper:

Maiti, B. (2017). Internet Usage and Academic Achievement of Adolescents of West Bengal: An Exploratory Study. IRA International Journal of Education and Multidisciplinary Studies (ISSN 2455-2526), 7(3), 270-278. doi:http://dx.doi.org/10.21013/jems.v7.n3.p12

(C) Institute of Research Advances

\section{(cc) BY-NC}

This work is licensed under a Creative Commons Attribution-Non Commercial 4.0 International License subject to proper citation to the publication source of the work.

Disclaimer: The scholarly papers as reviewed and published by the Institute of Research Advances (IRA) are the views and opinions of their respective authors and are not the views or opinions of the IRA. The IRA disclaims of any harm or loss caused due to the published content to any party. 


\begin{abstract}
Present study is a process to find out the effect of internet usage on the academic achievement of adolescents of West Bengal, specifically on the students of Higher Secondary level under the West Bengal Council of Higher Secondary Education. To study the impact thoroughly the investigator divided internet usage into three categories- Educational usage, Communicational usage and Recreational usage. Intending to fetch out the relationship of different types of internet usage with students' academic achievement as well as the gender difference regarding the internet usage, the researcher formulated some null hypotheses. To go through this study the investigator administered an internet usage questionnaire on 138 class XI students, selected by purposive sampling method from different schools under WBCHSE. Percentage of marks obtained by the adolescents in Madhyamik examination was treated as the academic achievement by them. The investigator used Pearson's Product Moment Correlation Coefficient and Independent Sample 't' test for testing the hypotheses. By the end of the study it was seen that Educational usage and Communicational usage of internet had no effect on their academic achievements, but there was negative effect of Recreational internet usage on their academic achievement. Also, boys and girls differed significantly in respect to their different internet usage.
\end{abstract}

Keywords: Academic achievement, Adolescents, Educational usage, Communicational usage, Recreational usage.

\title{
Introduction
}

We are now in the seventeenth year of the twenty first century. After passing through so many years through the history when we turn back to the past, we can say that, if the invention of fire was the beginning of the civilization with the imminence of human brain and science, then the invention of internet certainly shifted it onto another height and added an extra gem in its crown. When ARPAnet was developed by United State's defence department in the 1960s as the government weapon for the Cold War it was beyond anyone's imagination that one day it will become such a galactic network and every facet of our life will be engulfed by it. Today internet is everywhere including administration, business operation, education, communication, entertainment, social activity and so on. That's why nineteen years ago Young (1998)[1] precisely foretold -“And for all those who have not yet joined the internet generation, you probably have heard that the internet likely will become as routine a part of your life as television- and soon". (p.11).

Internet, the greatest advancement in the world of information technology enables an entrepreneur of Kolkata to make a deal with an alternative of Kansas City within no time; likewise, the ideas can also be exchanged between a researcher of Visva Bharati and a professional of University of Virginia through it. Literally internet is such a staggering, responsive, constantly moving virtual space beyond the trivial rim of region, age, condition etc. where continuous fusion-fission of information gratifies the knowledge thirst of Man. But as shadow follows the light, similarly usage of internet has its demerits too. As a whole the mode of outcome depends on the way by which it is being used. The scenario will become more clear if we cast our eyes on a specific internet related issue, viz. 'the impact of internet on students'

Hunley et.al (2005)[2] in their study, 'Adolescent computer use and academic investigated the relationship between home computer and internet use and academic achievement of tenth- grade adolescents. Questionnaire and seven-day time logs were used to gathered data from 101 participants who were recruited from science and social studies classes at three public high schools in three different school districts in south-western Ohio. Results did not reveal significant relationship between time spent on the computer at home and grade average. The total time spent on the computer was found to be highly correlated with daily logged documentation. The study pointed out the gender gap in the types of computer use. 
Anand (2007)[3] in his study, 'A study of time management: the correlation between video game usage and academic performance markers' analyzed the correlation between video game usage and academic performance. The samples used in this study were college students, randomly selected from five postsecondary institutions located in New York. The survey included questions that made distinctions between which types and titles of video games participants played the most. Scholastic Aptitude Test (SAT) and grade-point average (GPA) scores were used to gauge academic performance. The results showed that the amount of time a student spent playing video games had a negative correlation with students' GPA and SAT scores.

Kalra and Manani (2013)[4] investigated the effect of use of Social Networking sites on academic achievement among introverts and extroverts students of class XI of C.B.S.E. English medium schools of Agra City in their study, 'Effect of social networking sites on academic achievement among introverts and extroverts'. Results revealed that there was no significant difference between academic achievement of users and non users of Social Networking Sites. Even with personality differences among the students there was no significant difference found among extrovert and introvert students using and not using Social Networking Sites with reference to their academic achievement.

The above precedents across the world motivate the present researcher to find empirical evidences in order to shed light on some issues like- relationship between internet usage and academic achievement of the adolescents, difference between adolescent boys and girls in respect to their internet usage in the context of West Bengal.

In order to measure the impact of meticulous internet usage, an important independent variable of this study is divided into three categories:

1) Educational usage of internet: When internet is used for searching matters of education, viz., search for topics the individual is interested to know, search for topics from their syllabus, using online libraries etc.

2) Communicational usage of internet: When internet is used to communicate with others, viz., emailing, chatting, social networking etc.

3) Recreational usage of internet: When internet is used for own entertainment, viz., playing online games, downloading music/videos/images etc., surfing the web with no set purposes, etc.

\section{Objectives of the study}

1) To find out the relation between the educational usage of internet \& academic achievement of students.

2) To find out the relation between the communicational usage of internet \& academic achievement of students.

3) To find out the relation between the recreational usage of internet $\&$ academic achievement of students.

4) To know about the difference between boys \& girls in respect to their educational usage of internet.

5) To know about the difference between boys \& girls in respect to their communicational usage of internet.

6) To know about the difference between boys \& girls in respect to their recreational usage of internet.

\section{Hypotheses}

${ }^{1} \mathbf{H}_{\mathbf{0}}$. There is no significant correlation between the educational usage of internet \& academic achievement of students.

${ }^{2} \mathbf{H}_{\mathbf{0}}$. There is no significant correlation between the communicational usage of internet \& academic achievement of students. 
${ }^{3} \mathbf{H}_{\mathbf{0}}$. There does not remain any significant correlation between the recreational usage of internet \& academic achievement of students.

${ }^{4} \mathbf{H}_{\mathbf{0}}$. There is no significant difference between boys \& girls in respect to their educational usage of internet.

${ }^{5} \mathbf{H}_{\mathbf{0}}$. There is no significant difference between boys \& girls in respect to their communicational usage of internet.

${ }^{6} \mathbf{H}_{\mathbf{0}}$. There is no significant difference between boys \& girls in respect to their recreational usage of internet.

\section{Delimitations of the study}

1) The study was confined in southern part of West Bengal.

2) Only students of Class XI from different Bengali medium schools recognized by West Bengal Council for Higher Secondary Education were selected for data collection.

\section{Methodology of the research}

\section{Research approach}

The main aim of the present study is to explore the existing relationship between internet usage and academic achievement as well as gender differences regarding internet usage of adolescents. A descriptive research design is adopted by employing a survey technique to serve the purpose utmost.

2. Sample and sampling technique

Different High Schools from South Bengal were selected using random sampling method for data collection. Then 138 class XI students with internet access were chosen using purposive sampling technique.

\section{Tools used}

1) A paper and pencil type questionnaire, developed by the investigator himself with the help of experts, was used to know the internet usage habit of the adolescents.

2) Percentage of marks obtained by the adolescents in previous board examination i.e. in Madhyamik Examination (class X), conducted by West Bengal Board of Secondary education was treated as academic achievement.

\section{Procedure of data collection}

The questionnaire was supplied to 138 high school students who were in class XI. After getting the responses back researcher scrutinized it carefully. From all the responses 117 were found to be usable, among which 70 were from boys and 47 were from the girls.

\section{Analysis and interpretation of data}

Questionnaires were collected and scoring was done by using the scoring procedure. Descriptive statistic, Pearson's coefficient of correlation and t-test was used to analysis the data statistically.

Table No. 1 Group Statistics of the variables - Educational, Communicational, Recreational Usage of Internet \& Academic achievement

\begin{tabular}{|c|c|c|c|c|c|}
\hline & & $\begin{array}{c}\text { Educational } \\
\text { Usage }\end{array}$ & $\begin{array}{c}\text { Communicational } \\
\text { Usage }\end{array}$ & $\begin{array}{c}\text { Recreational } \\
\text { Usage }\end{array}$ & $\begin{array}{c}\text { Academic } \\
\text { Achievement }\end{array}$ \\
\hline \multirow{4}{*}{ Boys } & $\mathrm{N}$ & 70 & 70 & 70 & 70 \\
\cline { 2 - 6 } & Mean & 5.86 & 3.79 & 4.24 & 67.36 \\
\cline { 2 - 6 } & $\begin{array}{c}\text { Std. } \\
\text { Deviation }\end{array}$ & 2.704 & 2.776 & 2.362 & 16.550 \\
\cline { 2 - 6 } & Kurtosis & -.466 & .027 & .824 & -1.404 \\
\cline { 2 - 6 } & Skewness & .400 & .768 & 1.005 & .003 \\
\hline \multirow{3}{*}{ Girls } & $\mathrm{N}$ & 47 & 47 & 47 & 47 \\
\cline { 2 - 6 } & Mean & 4.57 & 2.47 & 2.26 & 77.47 \\
\cline { 2 - 6 } & Std. & 2.402 & 2.421 & 1.750 & 11.754 \\
\hline
\end{tabular}




\begin{tabular}{|c|c|c|c|c|c|}
\hline \multirow{4}{*}{} & Deviation & & & & \\
\cline { 2 - 6 } & Kurtosis & -.859 & .379 & .895 & -.899 \\
\cline { 2 - 6 } Total & Skewness & .617 & 1.015 & 1.038 & -.326 \\
\hline \multirow{4}{*}{} & $\mathrm{N}$ & 117 & 117 & 117 & 117 \\
\cline { 2 - 6 } & Mean & 5.34 & 3.26 & 3.44 & 71.42 \\
\cline { 2 - 6 } & $\begin{array}{c}\text { Std. } \\
\text { Deviation }\end{array}$ & 2.653 & 2.707 & 2.343 & 15.573 \\
\cline { 2 - 6 } & Kurtosis & -.534 & .150 & 1.078 & -1.109 \\
\cline { 2 - 6 } & Skewness & .500 & .853 & 1.028 & -.306 \\
\hline
\end{tabular}

For testing hypotheses ${ }^{1} \mathbf{H}_{0}$ to ${ }^{3} \mathbf{H}_{\mathbf{0}}$ researcher calculated Pearson's coefficient of correlation between the variables. Hypotheses will be tested respectively.

${ }^{1} \mathbf{H}_{\mathbf{0}}$. There is no significant correlation between the educational usage of internet \& academic achievement of students.

Table No. 2 Coefficient of Correlation between Educational Usage of Internet and Academic Achievement

\begin{tabular}{|c|c|c|c|}
\hline & & $\begin{array}{c}\text { Educational } \\
\text { Usage }\end{array}$ & Academic Achievement \\
\hline \multirow[t]{3}{*}{$\begin{array}{c}\text { Educational } \\
\text { Usage }\end{array}$} & $\begin{array}{c}\text { Pearson } \\
\text { Correlation }\end{array}$ & 1 & -.154 \\
\hline & Sig. (2-tailed) & & .097 \\
\hline & $\mathrm{N}$ & 117 & 117 \\
\hline \multirow[t]{3}{*}{$\begin{array}{c}\text { Academic } \\
\text { Achievement }\end{array}$} & $\begin{array}{c}\text { Pearson } \\
\text { Correlation }\end{array}$ & -.154 & 1 \\
\hline & Sig. (2-tailed) & .097 & \\
\hline & $\mathrm{N}$ & 117 & 117 \\
\hline
\end{tabular}

It is seen (TABLE NO. 2) that the coefficient of correlation between educational usage of internet and academic achievement is -.154 which is not significant. Thus it can be said that academic achievement is not depended on the educational usage of internet of adolescents.

${ }^{2} \mathbf{H}_{\mathbf{0}}$. There is no significant correlation between the communicational usage of internet \& academic achievement of students.

Table No. 3 Coefficient of Correlation between Communicational Usage of Internet and Academic Achievement

\begin{tabular}{|c|c|c|c|}
\hline \multirow{4}{*}{$\begin{array}{c}\text { Communication } \\
\text { al Usage }\end{array}$} & $\begin{array}{c}\text { Pearson } \\
\text { Correlation }\end{array}$ & Communicational Usage & Academic Achievement \\
\cline { 2 - 4 } & Sig. (2-tailed) & 1 & -.125 \\
\cline { 2 - 4 } & $\mathrm{N}$ & 117 & .181 \\
\hline \multirow{2}{*}{$\begin{array}{c}\text { Academic } \\
\text { Achievement }\end{array}$} & $\begin{array}{c}\text { Pearson } \\
\text { Correlation }\end{array}$ & -.125 & 117 \\
\cline { 2 - 4 } & Sig. (2-tailed) & .181 & 1 \\
\cline { 2 - 4 } & $\mathrm{N}$ & 117 & 117 \\
\hline
\end{tabular}

Table No. 3 shows the coefficient of correlation between communicational usage of internet and academic achievement is -.125 which is not significant. So it is clear that academic achievement is not depended on the communicational usage of internet of adolescents. 
${ }^{3} \mathbf{H}_{\mathbf{0}}$. There does not remain any significant correlation between the recreational usage of internet \& academic achievement of students.

Table No. 4 Coefficient of Correlation between Recreational Usage of Internet and Academic Achievement

\begin{tabular}{|c|c|c|c|}
\hline & Recreational Usage & $\begin{array}{c}\text { Academic } \\
\text { Achievement }\end{array}$ \\
\hline \multirow{2}{*}{$\begin{array}{c}\text { Recreational } \\
\text { Usage }\end{array}$} & Pearson Correlation & 1 & $-.263^{* *}$ \\
\cline { 2 - 4 } & Sig. (2-tailed) & & .004 \\
\cline { 2 - 4 } & $\mathrm{N}$ & 117 & 117 \\
\hline $\begin{array}{c}\text { Academic } \\
\text { Achievemen } \\
\mathbf{t}\end{array}$ & Pearson Correlation & $-.263^{* *}$ & 1 \\
\cline { 2 - 4 } & Sig. (2-tailed) & .004 & 117 \\
\cline { 2 - 4 } & $\mathrm{N}$ & 117 & \\
\hline$* *$ Correlation is significant at the 0.01 level (2-tailed) & \multicolumn{2}{|c}{} \\
\hline
\end{tabular}

It can be seen (TABLE NO. 4) that the coefficient of correlation between recreational usage of internet and academic achievement is -.263 which is significant at 0.01 level. So it is clear that academic achievement is negatively correlated with recreational usage of internet by adolescents.

${ }^{4} \mathbf{H}_{\mathbf{0}}$. There is no significant difference between boys \& girls in respect to their educational usage of internet.

Table No. 5 Group Statistics of Boys and Girls on Educational Usage of Internet

\begin{tabular}{|l|c|c|c|c|c|}
\hline & Gender & $\mathbf{N}$ & Mean & Std. Deviation & $\begin{array}{c}\text { Std. Error } \\
\text { Mean }\end{array}$ \\
\hline \multirow{2}{*}{ Educational Usage } & Boys & 70 & 5.86 & 2.704 & .323 \\
\cline { 2 - 6 } & Girls & 47 & 4.57 & 2.402 & .350 \\
\hline
\end{tabular}

It is observed (TABLE NO. 5) that the mean score and standard deviation of boys are different from that of the girls in respect to their educational usage of internet. Therefore, Independent sample ' $t$ ' test is opted to study the mean difference.

Table No. 6 Independent Sample 't' test between Boys and Girls on Educational Usage of Internet

\begin{tabular}{|c|c|c|c|c|c|c|}
\hline & \multicolumn{3}{|c|}{ Levene's Test for Equality of Variances } & \multicolumn{3}{|c|}{ t-test for Equality of Means } \\
\hline & & $\mathbf{F}$ & Sig. & $\mathbf{t}$ & df & Sig. (2-tailed) \\
\hline \multirow{2}{*}{$\begin{array}{c}\text { Educational } \\
\text { Usage } \\
\text { (Boys vs Girls) }\end{array}$} & Equal variances assumed & \multirow[t]{2}{*}{.200} & \multirow[t]{2}{*}{.656} & 2.629 & 115 & .010 \\
\hline & $\begin{array}{c}\text { Equal variances not } \\
\text { assumed }\end{array}$ & & & 2.691 & 106.279 & .008 \\
\hline
\end{tabular}

The analysis (TABLE NO. 6) shows that, in case of Leven's Test for Equality of Variance the calculated $F$ is .200 and corresponding $p$ value is .656 $(p>.05)$ for the variation in respect of gender. So, for educational usage of internet the variability in boys and girls are same, thus equal variance can be assumed. When we are comparing the mean scores of boys and girls, the calculated $\mathbf{t}_{(115)}$ is 2.629 and $p=$ $.010(p<.05)$. Hence' $t$ ' is significant at .05 level. So, it can be concluded that boys are significantly different from girls in respect to their educational usage of internet.

${ }^{5} \mathbf{H}_{0}$. There is no significant difference between boys \& girls in respect to their communicational usage of internet. 
Table No. 7 Group Statistics of Boys and Girls on Communicational Usage of Internet

\begin{tabular}{|c|c|c|c|c|c|}
\hline & Gender & $\mathbf{N}$ & Mean & $\begin{array}{c}\text { Std. } \\
\text { Deviation }\end{array}$ & $\begin{array}{c}\text { Std. Error } \\
\text { Mean }\end{array}$ \\
\hline $\begin{array}{c}\text { Communicational } \\
\text { Usage }\end{array}$ & Boys & 70 & 3.79 & 2.776 & .332 \\
\cline { 2 - 6 } & Girls & 47 & 2.47 & 2.421 & .353 \\
\hline
\end{tabular}

Table No. 7 reveals the difference of mean scores and standard deviation between boys and girls according to their communicational usage of internet. Thus it is decided to adopt Independent Sample ' $t$ ' test to see the mean difference.

Table No. 8 Independent Sample ' $t$ ' test between Boys and Girls on Communicational Usage of Internet

\begin{tabular}{|c|c|c|c|c|c|c|}
\hline & \multicolumn{3}{|c|}{ Levene's Test for Equality of Variances } & \multicolumn{3}{|c|}{ t-test for Equality of Means } \\
\hline & & $\mathbf{F}$ & Sig. & $\mathbf{t}$ & df & Sig. (2-tailed) \\
\hline \multirow{2}{*}{$\begin{array}{c}\text { Communicationa } \\
\text { I Usage } \\
\text { (Boys vs Girls) }\end{array}$} & Equal variances assumed & \multirow[t]{2}{*}{.767} & \multirow[t]{2}{*}{.383} & 2.647 & 115 & .009 \\
\hline & $\begin{array}{c}\text { Equal variances not } \\
\text { assumed }\end{array}$ & & & 2.719 & 107.306 & .008 \\
\hline
\end{tabular}

The analysis (TABLE NO. 8) shows that, in case of Leven's Test for Equality of Variance the calculated $F$ is .767 and corresponding $p$ value is $.383(p>.05)$ for the variation in respect of gender. So, for communicational usage of internet the variability in boys and girls are same, thus equal variance can be assumed. When we are comparing the mean scores of boys and girls, the calculated $\mathbf{t}_{(115)}$ is 2.647 and $p=.009(p<.05)$. Hence ' $\mathrm{t}$ ' is significant at .05 level. So, it can be concluded that there is significant difference between boys $\&$ girls in respect to their communicational usage of internet.

${ }^{6} \mathbf{H}_{0}$. There is no significant difference between boys \& girls in respect to their recreational usage of internet.

Table No. 9 Group Statistics of Boys and Girls on Recreational Usage of Internet

\begin{tabular}{|l|c|c|c|c|c|}
\hline & Gender & $\mathbf{N}$ & Mean & $\begin{array}{c}\text { Std. } \\
\text { Deviation }\end{array}$ & $\begin{array}{c}\text { Std. Error } \\
\text { Mean }\end{array}$ \\
\hline \multirow{2}{*}{ Recreational Usage } & Boys & 70 & 4.24 & 2.362 & .282 \\
\cline { 2 - 6 } & Girls & 47 & 2.26 & 1.750 & .255 \\
\hline
\end{tabular}

It is observed (TABLE NO. 9) that the mean score and standard deviation of boys are different from that of the girls in respect to their recreational usage of internet. Therefore, Independent sample ' $t$ ' test is opted to study the mean difference.

Table No. 10 Independent Sample't' test between Boys and Girls on Recreational Usage of Internet

\begin{tabular}{|c|c|c|c|c|c|c|}
\hline & \multicolumn{3}{|c|}{ Levene's Test for Equality of Variances } & \multicolumn{3}{|c|}{ t-test for Equality of Means } \\
\hline & & $\mathbf{F}$ & Sig. & $\mathbf{t}$ & $\mathbf{d f}$ & $\begin{array}{c}\text { Sig. (2- } \\
\text { tailed) }\end{array}$ \\
\hline \multirow{2}{*}{$\begin{array}{c}\text { Recreational } \\
\text { Usage } \\
\text { (Boys vs Girls) }\end{array}$} & $\begin{array}{c}\text { Equal variances } \\
\text { assumed }\end{array}$ & 4.333 & .040 & 4.929 & 115 & .000 \\
\cline { 2 - 5 } & $\begin{array}{c}\text { Equal variances not } \\
\text { assumed }\end{array}$ & & 5.222 & 113.816 & .000 \\
\hline
\end{tabular}

Table No.10 shows that, in case of Leven's Test for Equality of Variance the calculated $F$ is 4.333 and corresponding $p$ value is .040 $(p>.05)$ for the variation in respect of gender. So, for recreational usage of internet the variability in boys and girls are same, thus equal variance can be assumed. When we are comparing the mean scores of boys and girls, the calculated $\mathbf{t}_{(115)}$ is 4.929 and $p=$ $.000(p<.05)$. Hence ' $\mathrm{t}$ ' is significant at .05 level. So, it can be concluded that boys are significantly different from girls in respect to their recreational usage of internet. 


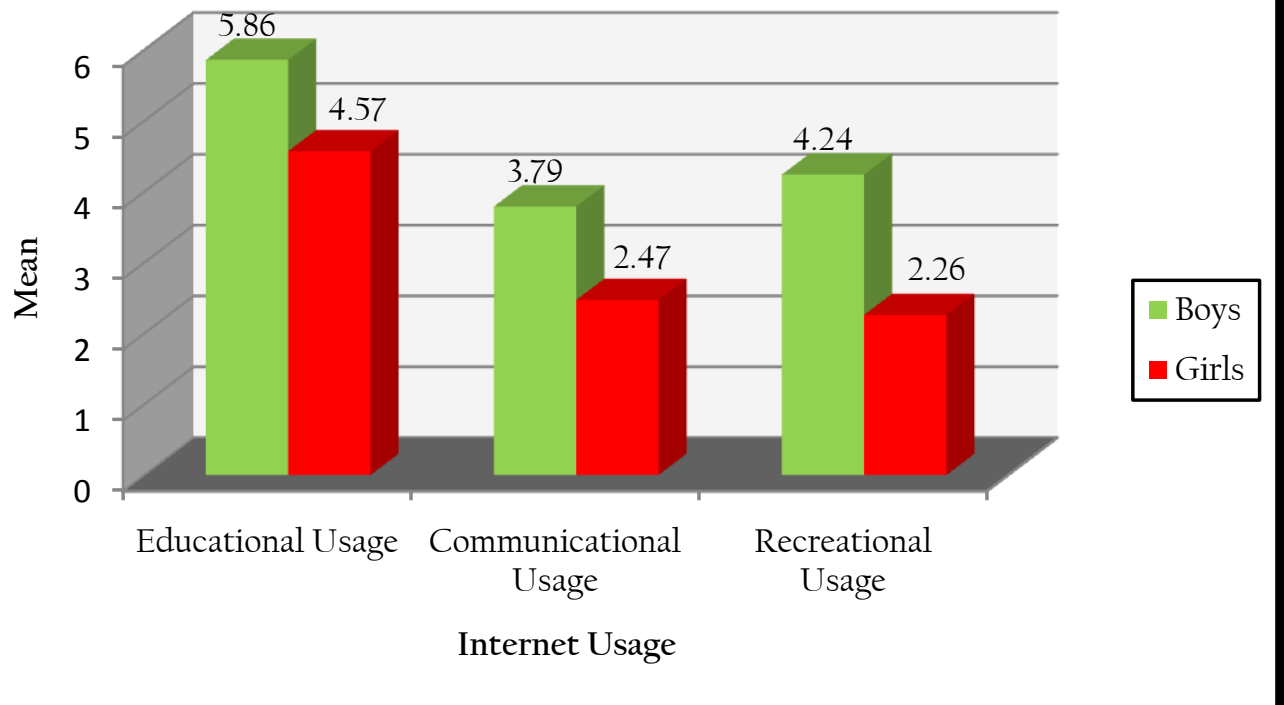

Figure 1. Mean scores of Boys and Girls regarding different Internet Usage.

\section{Findings and conclusion}

The findings of the study prove that academic achievements of the students' do not depend upon the educational and communicational usage of internet. But recreational usage has negative impact upon the students' academic outcome. Though the negative relationship between these two variables is slight, but it gives a clear indication that those students who spend more time to entertain themselves on the internet will be the poor academic achievers. It reaffirms the findings of the study of Anand (2007), which revealed that playing video game, one of the recreational usages, was negatively correlated with GPA and SAT scores. But differ from the findings of the study of Hunley et.al (2005), which revealed insignificant relationship between time spent on the computer and grade average. Result is also different from the study of Asdaque et.al (2010)[5], which stated that the students who used internet for academic purposes achieve good academic grade point. This study reveals that boys and girls of class XI differ considerably regarding their educational, communicational and recreational usage of internet. This outcome supports the findings of the study of Chen and Fu (2009)[6]. Present study pokes us about the negative bearing of recreational internet usage with student's academic achievement. So, keeping it in mind society, mainly parents and teacher should be concerned about the internet using culture of these young stars. According to Moll (2003)[7] it's time for the education system to adopt strict technology policies to minimize the ill-effect of internet upon the students. Indian Government had also introduced 'The Information Technology Act, 2000' to deal with the challenges students faces as cybercitizens. Hope, it will keep them on right track and internet will appear as a 'Digital Nymph' rather than a 'Digital Monster' in their life.

\section{References}

[1] Young, S. Kimberly. (1998). Caught in the Net: How to recognize the signs of internet addictionand a winning strategy for recovery. New York: John Wiley \& Sons, Inc.

[2] Hunley, Sawyer., et.al. (2005). Adolescent Computer Use and Academic Achievement. Adolescence, 40(158), 307-318.

[3] Anand, Vivek. (2007). A Study of Time Management: The Correlation Between Video Game Usage and Academic Performance Markers. Cyber Psychology \& Behavior, 10(4), 552-559. 
[4] Kalra, K. Raj., \& Manani, Preeti. (2013). Effect of Social Networking Sites on Academic Achievement among Introverts and Extroverts. Asian Journal of Social Sciences \& Humanities, 2(3), 401406.

[5] Asdaque, M.M., et.al. (2010). Effect of Internet on the Academic Performance and Social Life of University Students in Pakistan. Journal of Education and Sociology, December, 21-27.

[6] Chen, Su-Yen., \& Fu, Yang-Chih. (2009). Internet Use and Academic Achievement: Gender Differences in Early Adolescence. Adolescence, 44(176), 797-812.

[7] Moll, M. (2003). Computers And Kids: Pulling The Plug Can Protect The Planet. Phi Delta Kappan, 84(8). 600-602. 